\section{Evaluation of Low-volume Sprayers Used in Asian Citrus Psyllid Control Applications}

\author{
Clint Hoffmann ${ }^{1,8}$, Brad Fritz ${ }^{1}$, Dan Martin ${ }^{1}$, Ryan Atwood ${ }^{2}$, \\ Tim Hurner ${ }^{3}$, Mark Ledebuhr ${ }^{4}$, Matt Tandy ${ }^{5}$, John L. Jackson ${ }^{6}$, \\ and Gail Wisler ${ }^{7}$
}

\begin{abstract}
ADDITIONAL INDEX WORDs. technology, Diaphorina citri, greening
Summary. The asian citrus psyllid [Diaphorina citri (Sternorrhyncha: Psyllidae)] is a detrimental pest to citrus (Citrus spp.) crops when it serves as a vector of the pathogen that causes greening (huanglongbing). Transmission of this disease causes mottling, chlorosis, dieback, and reductions in fruit size and quality. Citrus producers have found that many pesticides, when applied properly, are very effective at suppressing or eliminating asian citrus psyllids in groves. Due to the threat of greening, several pesticides have been granted Special Local Needs registration for use in the state of Florida if the product is sprayed with a volume median diameter of $90 \mu \mathrm{m}$ or greater. A number of studies involving numerous citrus sprayers and a.i. were conducted to determine the droplet sizes generated by different sprayers operating under user-established settings and the adjustments required to those settings for the sprayers to meet the $90-\mu \mathrm{m}$ requirement. In the sprayer tests, it was found that reductions in engine speed or increases in flow rate were required to increase droplet sizes to meet the product label-required droplet size. As the equipment tested here represent the most typical application equipment used in Florida for asian citrus psyllid control, these results will provide applicators, growers, and extension agents with general guidelines to ensure that spray systems are operated in a manner that complies with label restrictions.
\end{abstract}

$\mathrm{T}$ The asian citrus psyllid is a detrimental pest to citrus crops when it serves as a vector of the pathogen that causes greening [huanglongbing (HLB)]. Transmission of this disease causes mottling, chlorosis, dieback, and reductions in

Mention of a trademark, vendor, or proprietary product does not constitute a guarantee or warranty of the product by the U.S. Department of Agriculture or U.S. Navy and does not imply its approval to the exclusion of other products that may also be suitable.

This study was supported in part by a grant from the Deployed War-Fighter Protection (DWFP) Research Program, funded by the U.S. Department of Defense through the Armed Forces Pest Management Board (AFPMB).

${ }^{1}$ U.S. Department of Agriculture-Agricultural Research Service-Areawide Pest Management Research Unit-Aerial Application Group, 2771 F\&B Road, College Station, TX 77845

${ }^{2}$ University of Florida, IFAS Extension, 1951 Woodlea Road, Tavares, FL 32778

${ }^{3}$ University of Florida, IFAS Extension, 4509 George Boulevard, Sebring, FL 33872

${ }^{4}$ Ledebuhr Industries, 795 Progress Court, Williamston, MI 48895

${ }^{5}$ Curtis DynaFog, 17335 U.S. Highway 31 North, Westfield, IN 46074

${ }^{6}$ Florida Citrus Industry Research Coordinating Council, 30205 SR 19, Tavares, FL 32778

${ }^{7}$ U.S. Department of Agriculture-Agricultural Research Service, National Programs, 5601 Sunnyside Avenue, Beltsville, MD 20705

${ }^{8}$ Corresponding author. E-mail: clint.hoffmann@ars. usda.gov. fruit size and quality (Halbert and Manjunath, 2004). Once a tree is infected, there is no cure, and trees may only live for another 5 to 8 years, potentially never bearing usable fruit. It is well established that the presence of asian citrus psyllids and the vectored pathogen necessitate chemical control in the form of pesticide applications (Tolley, 1990). Given the seriousness of the disease, it is important to protect even apparently disease-free trees (Aubert, 1990), especially with new growth flush (Aubert 1987). Recommended treatment intervals range from 10 to 13 treatments per year (Roistacher, 1996) to every 7 to $20 \mathrm{~d}$ (Gonzales and Viñas, 1981), with area-wide treatments being preferred (Aubert 1990). Supriyanto and Whittle (1991) recommend high-efficacy pesticides as essential to provide sufficient control to significantly delay a greening epidemic. It can be further conjectured that optimal application techniques also are critical to obtaining maximum biological control of asian citrus psyllids.

Stover et al. (2002), in a survey to indentify current spray application practices on citrus crops in Florida, identified three predominate sprayer types, including two airblast sprayers at mid- and high-volume application rates and a low-volume application rate air-assisted sprayer, with spray rates ranging from 25 to $750 \mathrm{gal} /$ acre. Sprayer type is generally selected by the operator based on experience and/or perceived coverage and deposition of spray material within the citrus canopy. The selected sprayers can typically be modified to generate spray plumes that fit tree contours through changes in nozzle numbers, and orientation of and/or oscillation of airflow (Stover et al., 2003). With the need for numerous spray treatments for asian citrus psyllid control, applicators are looking to and adapting for use a number of spray application machines initially targeted for the mosquito vector control industry. Machines that apply agrochemical products at these low-volume rates allow applicators to respond to the need to treat large numbers of acres repeatedly in a timely manner. These machines can produce droplets with volume median diameters that range from 5 to $210 \mu \mathrm{m}$, depending on spray solution and equipment setup (Hoffmann et al., 2007a).

The list of pesticides approved for application to control asian citrus psyllids in Florida is limited. As a result of the urgent need for control, applicators in Florida have been granted Special Local Needs provisions on a number of insecticides, including spinetoram (Delegate ${ }^{\circledR}$ WG; Dow

\begin{tabular}{llll}
\hline $\begin{array}{l}\text { Units } \\
\begin{array}{l}\text { To convert U.S. to SI, } \\
\text { multiply by }\end{array}\end{array}$ & U.S. unit & SI unit & $\begin{array}{l}\text { To convert SI to U.S., } \\
\text { multiply by }\end{array}$ \\
\hline 0.3048 & $\mathrm{ft}$ & $\mathrm{m}$ & 3.2808 \\
3.7854 & $\mathrm{gal}$ & $\mathrm{L}$ & 0.2642 \\
9.3540 & gal/acre & $\mathrm{L} \cdot \mathrm{ha}^{-1}$ & 0.1069 \\
2.54 & inch $(\mathrm{es})$ & $\mathrm{cm}$ & 0.3937 \\
1 & micron & $\mu \mathrm{m}$ & 1 \\
0.4470 & mph & $\mathrm{m} \cdot \mathrm{s}^{-1}$ & 2.2369 \\
70.0532 & oz/acre & $\mathrm{g} \cdot \mathrm{ha}^{-1}$ & 0.0143 \\
6.8948 & $\mathrm{psi}$ & $\mathrm{kPa}$ & 0.1450
\end{tabular}


AgroSciences, Indianapolis), diflubenzuron (Micromite ${ }^{\circledR}$ 80WGS; Chemtura, Middlebury, CT), fenpropathrin (Danitol 2.4 EC; Valent, Walnut Creek, CA), and zeta-cypermethrin (Mustang; FMC, Philadelphia). All of these Special Local Needs labels require air-blast or air-assisted sprayers with application rates of no less than $2 \mathrm{gal} / \mathrm{acre}$ and with volume median droplet diameters of $90 \mu \mathrm{m}$ or larger. Most labels allow the addition of adjuvants or other tank-mix partners as long as the other restrictions are maintained; however, fenpropathrin does not allow use of additional adjuvants. No information is given regarding the reasoning behind the $90-\mu \mathrm{m}$ lower limit, though it is likely based on risk assessment analysis for spray drift. The Special Local Needs labels also do not specify an upper limit on the droplet size. Given that spray droplet size is dependent on and changes with varying combinations of spray equipment, equipment setup, and spray product (Hoffmann et al., $2007 \mathrm{~b}$ ), the objectives of this work were: 1) evaluate three sprayers, under laboratory conditions, for droplet size produced from a.i. formulations and the necessary equipment adjustments needed to meet the Special Local Needs label; 2) conduct "onsite" evaluations of production application equipment for droplet size when operating under normal conditions; 3 ) adjust the individual sprayer's operating parameters to produce a volume median diameter of $90 \mu \mathrm{m}$ or greater to ensure compliance with the Special Local Needs labels; and 4) document the general operational modifications required for machine type to provide guidance for future spray calibrations.

\section{Materials and methods}

Sprayer droplet size testing was completed in two stages: one looking at three sprayers and five a.i. under laboratory conditions and the second, a field-based evaluation of production sprayers brought to a central location by local applicators. The first laboratory-based work was conducted at the U.S. Department of AgricultureAgricultural Research Service (USDAARS) Areawide Pest Management Research Unit's Riverside campus facilities in College Station, TX. The three sprayers to be evaluated were provided by the equipment manufacturers. The field-based evaluations were conducted at two locations in central Florida. Both sets of trials followed the same testing protocols with the exception of the field-based trials not using a.i. formulations. These procedures, along with greater details on the site-specific testing, are discussed further in the following sections.

General testing PRocedures. To evaluate the droplet size produced by a particular sprayer and spray formulation combination, the sprayer was first operated under its normal factory or user-established settings. Basically, the sprayer was initially operated as-is. A droplet measurement system (Sympatec, Clausthal, Germany) mounted on a custom-made forklift mount was used to measure droplet size at the sprayer nozzle outlet. The unit was positioned such that the location of measurement was $\approx 1$ to $2 \mathrm{~m}$ from the outlet of the sprayer (Fig. 1). This distance varied somewhat from sprayer to sprayer depending on the droplet density of the resulting spray cloud and the width of the spray plume. Wider spray plumes required a closer distance to avoid depositing spray material on the lenses of the droplet measurement unit. Denser sprays required further distance to insure that the spray cloud density did not prevent the diffracted laser light from reaching the measurement sensor. The spray cloud from the sprayer was directed through the laser beam for 10 to $20 \mathrm{~s}$ during which time droplet size measurements of the spray cloud were made. The time that the spray cloud was directed through the optical path of the laser varied between sprayers depending on the width of the spray plume generated by the sprayer. The entire spray plume for each sprayer was measured by traversing the laser through the plume using the forklift (ASTM International, 2009). Three replicated measures were made for each unique piece of equipment and specific set of operational conditions.

Droplet SIZING SYSTEM. The Helos laser diffraction droplet sizing system (Sympatec), which uses a 623$\mathrm{nm}$ helium-neon laser, was fitted with an R5 lens, resulting in a dynamic size range from 0.5 to $875 \mu \mathrm{m}$ in 32 sizing bins. The authors found that when using the laser system under adverse conditions (outdoors and mounted to a forklift), the last channel (i.e., sizing bins) of the Helos system should be turned off such that it is not factored into the droplet size measurement results. This channel represents the largest droplet size and tends to pick up some "noise" or random signals that typically result from equipment vibration or scattered ambient light. With this channel turned off, the dynamic range of the instrument was from 0.5 to $735 \mu \mathrm{m}$. These channels were not turned off if any droplets were measured within two sizing bins of the nearest deactivated channel.

The spray droplet size data were determined and reported as a mean and standard deviation corresponding to the data measured during the three replications for each combination of sprayer and pesticide. Means and standard deviations of the volume median diameter [VMD or $\mathrm{D}_{\mathrm{V} 0.5}$ (ASTM International E1620-97, 2004)], $D_{\mathrm{V} 0.1}$, and $D_{\mathrm{V} 0.9}$ were determined. The $\mathrm{D}_{\mathrm{V} 0.5}$ is the droplet diameter in micrometers where $50 \%$ of the spray volume is contained in droplets smaller than this value (ASTM

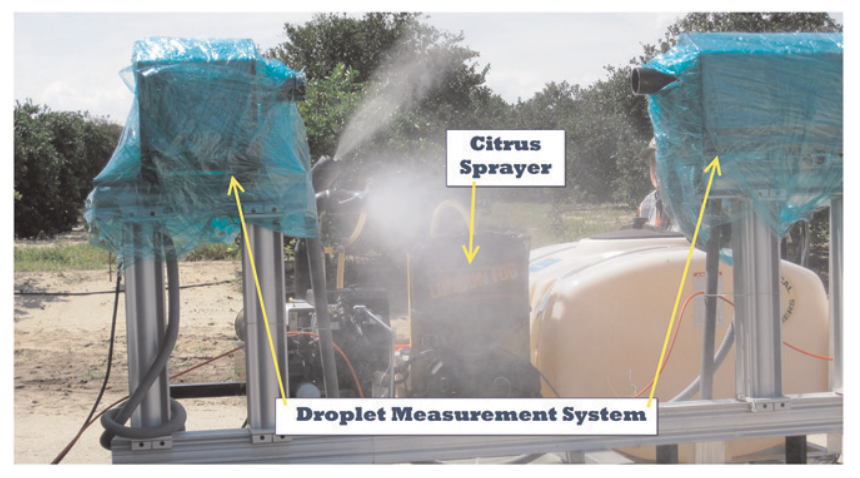

Fig. 1. Testing setup showing the droplet measurement system with the spray plume from the citrus sprayer directed through the laser beam of the droplet measurement system. 
Standard E1620, 2004). Similarly, the $\mathrm{D}_{\mathrm{V} 0.1}$ and $\mathrm{D}_{\mathrm{V} 0.9}$ values are the diameters at which $10 \%$ and $90 \%$, respectively, of the spray volume is contained in droplets of these sizes.

ACtive IngRedient Tests. For the laboratory studies, five a.i. along with water plus a nonionic surfactant (NIS) were used. The use of a specially designed scrubbing system allowed for the use of these a.i. without adverse environmental impacts. Three liquid-based products were used: malathion (Malathion 5EC; Drexel Chemical, Memphis, TN), dimethoate (Dimethoate 4E; Arysta LifeScience North America, Cary, NC), and fenpropathrin. Two of the products were wettable powders: diflubenzuron and spinetoram. The rates at which these products were tested are shown in Table 1. For all a.i. tests, spray rates were maintained at $3 \mathrm{gal} /$ acre. For each of the three sprayers tested, the first step was to run the sprayer at the factory settings using water to determine a benchmark for further modifications. Depending on the measured $\mathrm{D}_{\mathrm{V} 0.5}$, engine speed was modified such that the $90-\mu \mathrm{m}$ lower size requirement was met. The goal for each a.i. formulation tested was to determine the appropriate engine speed settings that resulted in compliance with the Special Local Needs permit.

Citrus sprayer Calibration RoDEos. The field evaluations were organized by the Florida Extension Service in Lake Placid, FL, and Haines City, FL. Growers and applicators in the region were invited to bring their equipment to these locations for droplet size measurements. Thirty-three machines were evaluated representing

Table 1. Five a.i. (three liquid and two wettable powders) and the rates at which they were used in the sprayer calibration trials.

\begin{tabular}{lc}
\hline $\begin{array}{l}\text { Liquid } \\
\text { formulation }\end{array}$ & $\begin{array}{c}\text { Application rate } \\
(\text { oz/acre a.i. })^{\mathrm{z}}\end{array}$ \\
\hline Malathion & 9.0 \\
Dimethoate & 13.9 \\
Fenpropathrin & 6.2 \\
Wettable & Application rate \\
powders & 5.0 \\
Diflubenzuron & 1.0 \\
Spinetoram & \\
\hline
\end{tabular}

${ }^{2} 1 \mathrm{oz} / \mathrm{acre}=70.0532 \mathrm{~g} \cdot \mathrm{ha}^{-1}$.
16 different models of sprayers. Water with $0.25 \%$ volume/volume addition of a NIS (R-11; Wilbur-Ellis, Walnut Creek, CA) was used during these tests as there were a large number of spray trials conducted and a large number of people involved. This prevented any environmental contamination or adverse health effects. The water plus NIS solution simulates most water-based insecticide sprays well (Hoffmann et al., 2007a, $2007 b$ ). Each sprayer tested was initially run at the user settings. Based on the measured $\mathrm{D}_{\mathrm{V} 0.5}$, engine speed and, in a few cases, sprayer pressure were adjusted until the 90$\mu \mathrm{m}$ size requirement was met. Typically, engine speed was first reduced to its minimum level and if the resulting measured $\mathrm{D}_{\mathrm{V} 0.5}$ was still less than $90 \mu \mathrm{m}$, spray pressure was increased.

An example of the data reports that were provided to each of the applicators is shown in the Appendix (Fig. 2).

\section{Results}

ACTIVE INGREDIENT TESTS WITH THREE SPRAYERS. Final equipment settings required to meet the $\mathrm{D}_{\mathrm{V} 0.5} 90$ $\mu \mathrm{m}$ size requirement for each a.i. are shown in Tables 2 through 4 for the three sprayers tested. Droplet size at the factory settings for water and water plus NIS are also included for reference. For the London Fog model 18-20 sprayer (London Fog, Long Lake, MN) (Table 2), initial testing with water and water plus NIS with the machine operating at 2810 and $1850 \mathrm{rpm}$, respectively, and a rate of $1.9 \mathrm{~L} \cdot \mathrm{min}^{-1}$ produced $\mathrm{D}_{\mathrm{V} 0.5}$ of $57.8 \pm$ 13.2 and $85.9 \pm 1.2 \mu \mathrm{m}($ mean \pm SD of three replications), respectively. Two of the a.i. formulations, diflubenzuron and spinetoram, produced $\mathrm{D}_{\mathrm{V} 0.5}$ values that were at or near the $90-\mu \mathrm{m}$ requirement while operating the sprayer at $1500 \mathrm{rpm}$ while two, fenpropathrin and malathion, required reducing the engine speed to $1350 \mathrm{rpm}$. The dimethoate formulation was such that even at the lowest engine speed setting (1350 rpm), the $90-\mu \mathrm{m}$ size requirement could not be met.

For the Curtec sprayer (Curtec of Florida, Vero Beach, FL), water and water plus NIS resulted in $\mathrm{D}_{\mathrm{V} 0.5}$ that were greater than $90 \mu \mathrm{m}$ at factory settings. Dimethoate and diflubenzuron formulation also achieve the $90-\mu \mathrm{m}$ requirement at the factory settings, while the malathion, spinetoram, and fenpropathrin formulation required engine speeds to be reduced to 4800,4000 , and 4000 rpm, respectively.

For the Proptec sprayer (Ledebuhr Industries, Williamston, MI), water and water plus NIS resulted in $\mathrm{D}_{\mathrm{V} 0.5}$ values that met the $90-\mu \mathrm{m}$ requirement. Spinetoram and diflubenzuron formulations also met the $90-\mu \mathrm{m}$ requirement at the $5100-\mathrm{rpm}$ factory setting, while malathion and fenpropathrin formulations required the engine speed to be reduced to $3500 \mathrm{rpm}$.

Citrus sprayer calibration RODEOS: S INGLE M ACH INE eVAluations. During the calibration rodeos, there were 17 unique models of machines evaluated. Fourteen of the models only had one machine of that type that was tested. Two, the Dyna-Fog Ag-Mister LV-8 (Curtis Dyna-Fog, Westfield, IN) and the London Fog model 18-20, had multiple machines of that type tested.

Of the individual machines tested, eight had a $D_{\mathrm{V} 0.5}$ of 90 um or greater (Table 5). Three of the remaining sprayers were able to be adjusted via spray pressure or engine speed to achieve a $\mathrm{D}_{\mathrm{V} 0.5}$ near or greater than $90 \mu \mathrm{m}$. One of the sprayers, MaxCharge ES100 (Electrostatic Spraying Systems, Watkinsville, GA), was designed to generate droplets with a $D_{\mathrm{V} 0.5}$ of between 30 and $40 \mu \mathrm{m}$ to optimize the electrostatic charge that it imparts to the spray droplets.

There were 14 Dyna-Fog AgMister LV-8 (LV-8) and six London Fog model 18-20 citrus sprayers evaluated in the calibration rodeos (Table 6). Each row of data presented in Table 6 represents a unique machine. These machines were all of different age, levels of maintenance, degree of user modification, and standard operating settings thus variation in spray droplet size among the machine was expected. Of the $14 \mathrm{LV}-8$ sprayers, four were version 1 (LV-8$\mathrm{V} 1)$, one was version 2 (LV-8-V2), and nine sprayers contained some modifications of pumps and spray lines that made it difficult to distinguish a specific version. Therefore, all data are presented by individual machine, with no attempt to characterize 
Table 2. Effects of a.i. and engine speed on spray atomization for the London Fog model 18-20 sprayer (London Fog, Long Lake, MN).

\begin{tabular}{|c|c|c|c|c|c|}
\hline \multirow[b]{2}{*}{ Formulation } & \multirow[b]{2}{*}{$\begin{array}{c}\text { Engine speed } \\
(\mathrm{rpm})\end{array}$} & \multirow{2}{*}{$\begin{array}{l}\text { Rate per } \\
\text { atomizer } \\
(\mathrm{gal} / \mathrm{min})^{\mathrm{z}}\end{array}$} & \multicolumn{3}{|c|}{ Droplet size $\mathrm{e}^{\mathrm{y}}$} \\
\hline & & & $\begin{array}{c}\mathrm{D}_{\mathrm{v0.1}} \mathrm{y} \\
(\mu \mathrm{m} \pm \mathrm{sD})\end{array}$ & $\begin{array}{c}\mathrm{D}_{\mathrm{V} 0.5} \\
(\mu \mathrm{m} \pm \mathrm{SD})\end{array}$ & $\begin{array}{c}\mathrm{D}_{\mathrm{V} 0.9} \\
(\mu \mathrm{m} \pm \mathrm{sD})\end{array}$ \\
\hline Water $+0.25 \%$ NIS $^{\mathrm{x}}$ & 1850 & 0.6 & $30.2 \pm 2.3$ & $85.9 \pm 1.2$ & $214.7 \pm 14.8$ \\
\hline Diflubenzuron & 1500 & 0.6 & $38.1 \pm 0.4$ & $94.0 \pm 2.7$ & $305.5 \pm 6.5$ \\
\hline Spinetoram & 1500 & 0.6 & $35.1 \pm 0.5$ & $86.4 \pm 0.6$ & $260.7 \pm 12.9$ \\
\hline Dimethoate & 1350 & 0.6 & $30.0 \pm 2.7$ & $79.6 \pm 2.8$ & $205.1 \pm 52.7$ \\
\hline
\end{tabular}

${ }^{\mathrm{z}} \mathrm{l} \mathrm{gal}=3.7854 \mathrm{~L}$.

${ }^{y} D_{\mathrm{V} .01}, D_{\mathrm{V} .05}$, and $\mathrm{D}_{\mathrm{V} .09}=$ the droplet diameter where $10 \%, 50 \%$, and $90 \%$, respectively, of the spray volume is contained in droplets smaller than this value. Values represent the mean of three replications; $1 \mu \mathrm{m}=1$ micron.

${ }^{\mathrm{x}} \mathrm{NIS}=$ nonionic surfactant (R-11; Wilbur-Ellis, Walnut Creek, CA).

Table 3. Effects of a.i. and engine speed on spray atomization for the Curtec sprayer (Curtec of Florida, Vero Beach, FL).

\begin{tabular}{|c|c|c|c|c|c|}
\hline \multirow[b]{2}{*}{ Formulation } & \multirow[b]{2}{*}{$\begin{array}{c}\text { Engine speed } \\
(\mathrm{rpm})\end{array}$} & \multirow{2}{*}{$\begin{array}{l}\text { Rate per } \\
\text { atomizer } \\
(\mathrm{gal} / \mathrm{min})^{\mathrm{z}}\end{array}$} & \multicolumn{3}{|c|}{ Droplet size ${ }^{y}$} \\
\hline & & & $\begin{array}{c}\mathrm{D}_{\mathrm{V} 0.1} \\
(\mu \mathrm{m} \pm \mathrm{sD})\end{array}$ & $\begin{array}{c}\mathrm{D}_{\mathrm{V} 0.5} \\
(\mu \mathrm{m} \pm \mathrm{SD})\end{array}$ & $\begin{array}{c}\mathrm{D}_{\mathrm{V} 0.9} \\
(\mu \mathrm{m} \pm \mathrm{sD})\end{array}$ \\
\hline Water & 5100 & 0.3 & $41.3 \pm 9.4$ & $111.8 \pm 12.8$ & $173.6 \pm 17.9$ \\
\hline Water $+0.25 \%$ NIS $^{\mathrm{x}}$ & 5100 & 0.3 & $35.3 \pm 5.2$ & $94.9 \pm 4.6$ & $149.1 \pm 4.2$ \\
\hline Dimethoate & 5100 & 0.3 & $37.9 \pm 5.9$ & $96.7 \pm 11.0$ & $167.3 \pm 11.5$ \\
\hline Malathion & 4800 & 0.3 & $31.2 \pm 1.3$ & $88.9 \pm 0.6$ & $168.7 \pm 9.0$ \\
\hline Fenpropathrin & 4000 & 0.3 & $44.3 \pm 1.7$ & $113.2 \pm 2.9$ & $218.6 \pm 33.5$ \\
\hline
\end{tabular}

${ }^{\mathrm{z}} 1 \mathrm{gal}=3.7854 \mathrm{~L}$.

${ }^{y} D_{\mathrm{V} .01}, D_{\mathrm{V} .05}$, and $\mathrm{D}_{\mathrm{V} .09}=$ the droplet diameter where $10 \%, 50 \%$, and $90 \%$, respectively, of the spray volume is contained in droplets smaller than this value. Values represent the mean of three replications; $1 \mu \mathrm{m}=1$ micron.

${ }^{x} \mathrm{NIS}=$ nonionic surfactant $(\mathrm{R}-11$; Wilbur-Ellis, Walnut Creek, CA).

Table 4. Effects of a.i. and engine speed on spray atomization for the Proptec sprayer (Ledebuhr Industries, Williamston, MI).

\begin{tabular}{|c|c|c|c|c|c|}
\hline \multirow[b]{2}{*}{ Formulation } & \multirow[b]{2}{*}{$\begin{array}{c}\text { Engine speed } \\
(\mathrm{rpm})\end{array}$} & \multirow{2}{*}{$\begin{array}{l}\text { Rate per } \\
\text { atomizer } \\
(\mathrm{gal} / \mathrm{min})^{\mathrm{z}}\end{array}$} & \multicolumn{3}{|c|}{ Droplet size ${ }^{y}$} \\
\hline & & & $\begin{array}{c}\mathrm{D}_{\mathrm{V} 0.1} \\
(\mu \mathrm{m} \pm \mathrm{SD})\end{array}$ & $\begin{array}{c}D_{\mathrm{V} 0.5} \\
(\mu \mathrm{m} \pm \mathrm{sD})\end{array}$ & $\begin{array}{c}\mathrm{D}_{\mathrm{V} 0.9} \\
(\mu \mathrm{m} \pm \mathrm{sD}) \\
\end{array}$ \\
\hline Water $+0.25 \%$ NIS $^{x}$ & 5100 & 0.36 & $33.0 \pm 4.2$ & $94.9 \pm 15.8$ & $193.0 \pm 21.6$ \\
\hline Malathion & 3500 & 0.36 & $33.7 \pm 1.6$ & $91.6 \pm 4.0$ & $173.6 \pm 3.8$ \\
\hline Spinetoram & 5100 & 0.36 & $32.6 \pm 2.0$ & $97.6 \pm 5.9$ & $165.8 \pm 7.0$ \\
\hline
\end{tabular}

${ }^{\mathrm{z}} \mathrm{l} \mathrm{gal}=3.7854 \mathrm{~L}$.

${ }^{y} D_{V .01}, D_{V .05}$, and $D_{\mathrm{V} .09}=$ the droplet diameter where $10 \%, 50 \%$, and $90 \%$, respectively, of the spray volume is contained in droplets smaller than this value. Values represent the mean of three replications; $1 \mu \mathrm{m}=1$ micron.

${ }^{\mathrm{x}} \mathrm{NIS}=$ nonionic surfactant (R-11; Wilbur-Ellis, Walnut Creek, CA).

general sprayer model performance. For each machine tested, the droplet size under the initial operational settings is presented followed by the droplet size at the adjusted settings. Typically, for the LV-8 and LV-8-V2, decreasing the engine rpm resulted in increased droplet size such the $90-\mu \mathrm{m}$ size requirement was met. There were several of the LV-8 machines that, even with maximum reduction of the engine speed, the $90-\mu \mathrm{m}$ level was not met. Each of the individual machines tested had unique lower engine speed, again due to variability in machine age, maintenance, and level of modification. For the LV-8-Vl machines tested, similar adjustments in engine speed did not result in sufficient increase in droplet size. The LV-8-Vl has a smaller pump and small diameter tubing leading to each of the spray nozzles, which limits flow output and thereby the ability to generate larger droplets.

The London Fog model 18-20 citrus sprayers followed similar trends 
Table 5. Spray droplet size measurements from sprayers in the citrus spray calibration rodeo with the original setting results followed by the adjusted setting results for a water plus nonionic surfactant solution. The sprayers were adjusted to comply with the droplet size requirements of the Special Local Needs permits granted to some insecticides in the State of Florida.

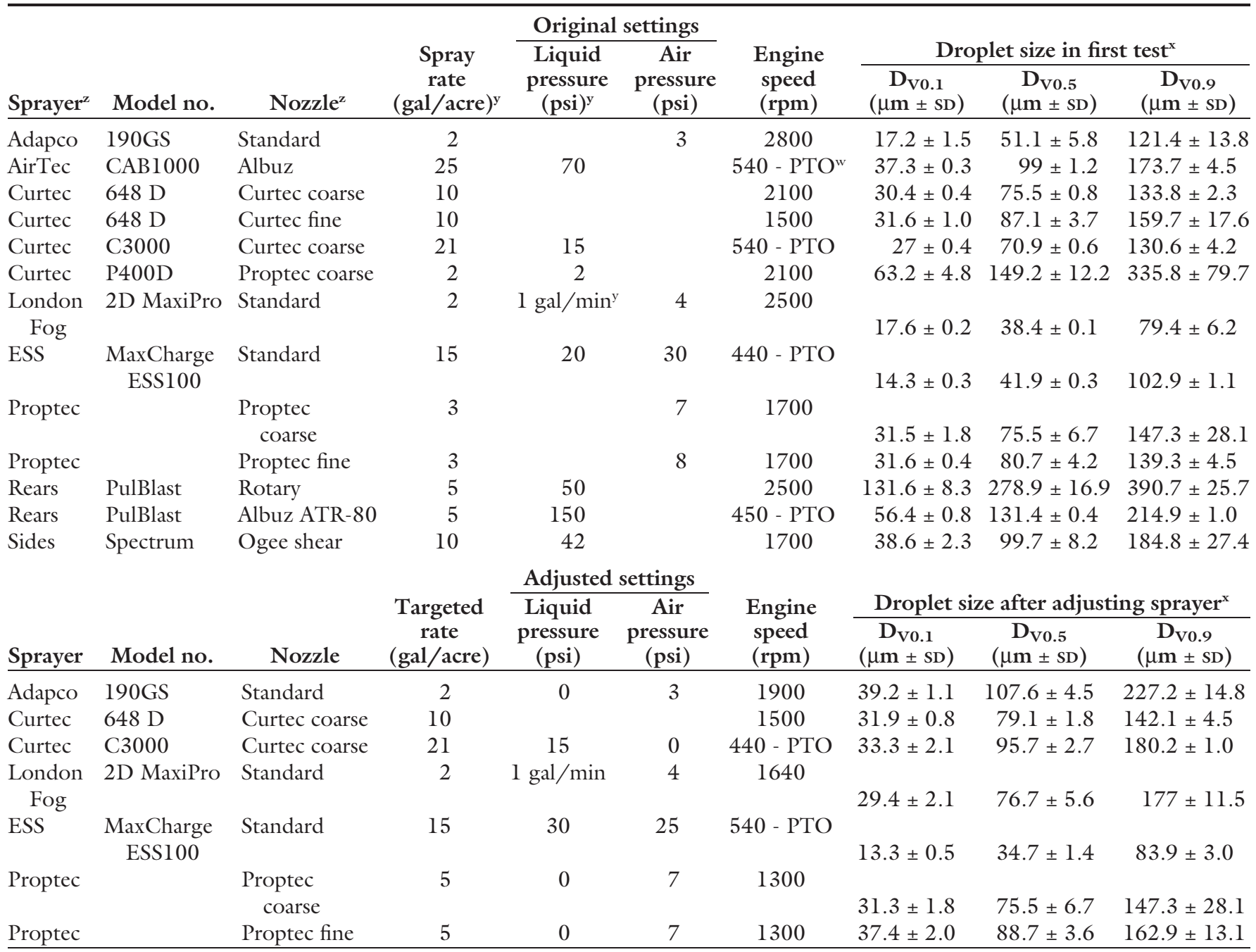

${ }^{2}$ Adapco (Sanford, FL); AirTec (AirTec Sprayers, Winter Haven, FL); Curtec (Curtec of Florida, Vero Beach, FL); London Fog (Long Lake, MN); ESS (Electrostatic Spraying Systems, Watkinsville, GA); Proptec (Ledebuhr Industries, Williamston, MI); Rears (Rears Manufacturing, Eugene, OR); Sides (Goldthwaite, TX); Albuz (Spirit River, AB, Canada); Ogee (Spectrum Electrostatic Sprayers, Houston).

y $\mathrm{gal} /$ acre $=9.3540 \mathrm{~L} \cdot \mathrm{ha}^{-1}, \mathrm{l} \mathrm{psi}=6.8948 \mathrm{kPa}, \mathrm{l}$ gal $=3.7854 \mathrm{~L}$

${ }^{x} \mathrm{D}_{\mathrm{V} .01}, \mathrm{D}_{\mathrm{V} .05}$, and $\mathrm{D}_{\mathrm{V} .09}=$ the droplet diameter where $10 \%, 50 \%$, and $90 \%$, respectively, of the spray volume is contained in droplets smaller than this value. Values represent the mean of three replications; $1 \mu \mathrm{m}=1$ micron.

wPower take-off.

as the LV-8s. With a single exception, reducing the engine speed increased $\mathrm{D}_{\mathrm{V} 0.5}$ values such that the $90-\mu \mathrm{m}$ size requirement was met.

\section{Conclusions}

In response to the need for accurate droplet size assessments of application equipment used in the control of the asian citrus psyllid in Florida, a variety of field application sprayers were evaluated to determine if the applied sprays met the Special Local Needs labeling requirements of volume median diameters of $90 \mu \mathrm{m}$ or greater. Initially, a series of studies was conducted across three typical spray systems and five a.i. to determine typical machine operating characteristics and resulting droplet sizes. From these tests, it was found that for typical air-blast type sprayers, reductions in engine speed were required to reduce air-shear atomization to increase droplet sizes to the required size. For air-assisted sprayers, this also held true with the addition that increased flow rate also potentially increased droplet size. Following these initial assessments, a series of droplet sizing rodeos were held in Florida to measure spray droplet size from applicator- and grower-owned citrus sprayers operating in "as-is" conditions. Based on the resulting spray droplet size, the sprayer settings were adjusted such that the resulting droplet size would comply with the label requirements. Following the trends seen in the initial round of testing, the majority of the sprayers was adjusted via the engine speed or spray pressure such that the resulting spray's volume median diameter was greater than or equal to $90 \mu \mathrm{m}$. As the equipment tested here represent the most typical application equipment used in Florida for asian citrus psyllid control, these results will provide applicators, growers, and extension agents with general guidelines to 


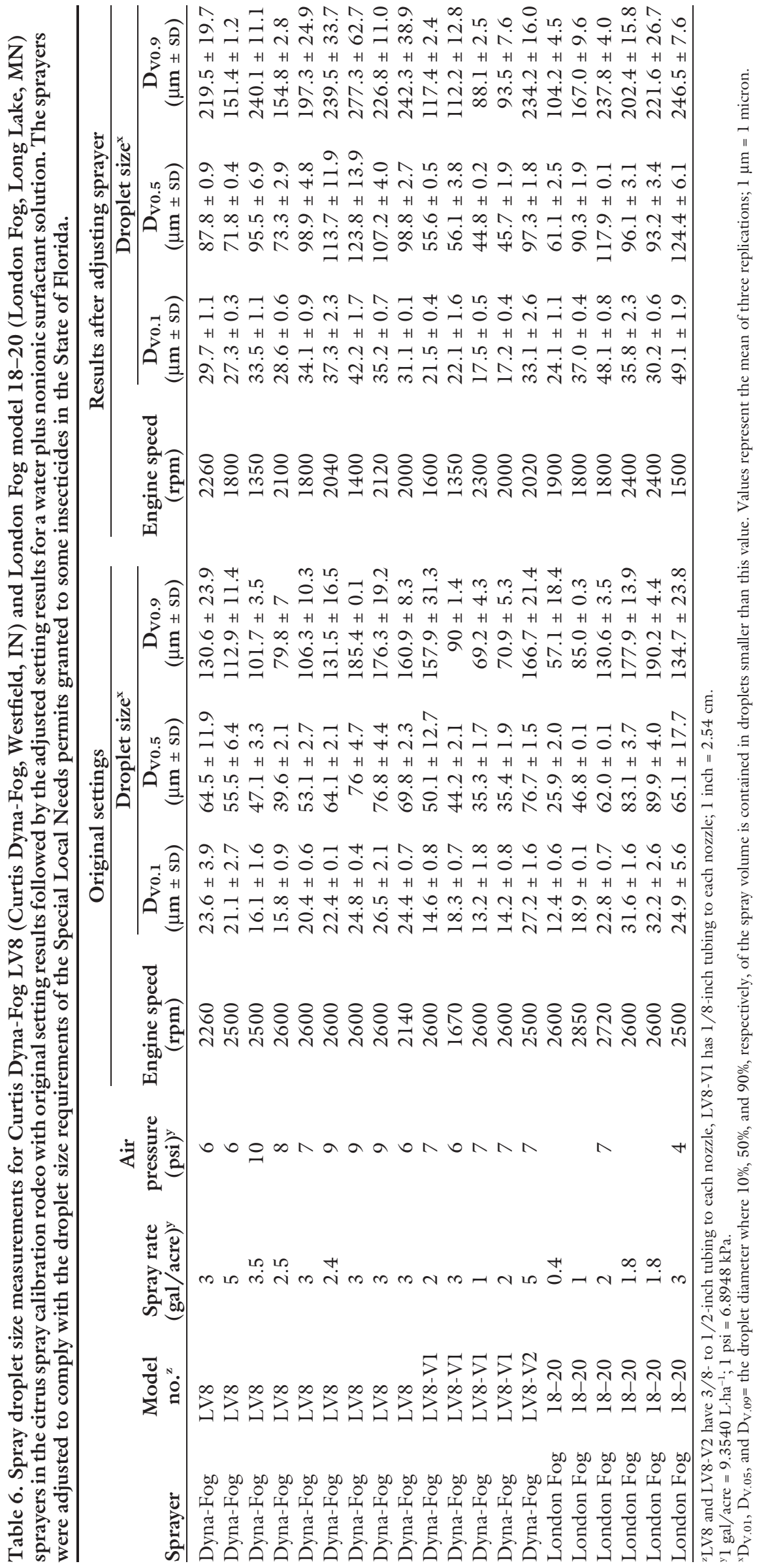

insure that spray systems are operated in a manner that complies with label restrictions.

\section{Literature cited}

ASTM International. 2004. ASTM E1620-97(2004) Standard terminology relating to liquid particles and atomization. ASTM International, West Conshohocken, PA.

ASTM International. 2009. ASTM E1260-03(2009) Standard test method for determining liquid drop size characteristics in a spray using optical nonimaging light-scattering instruments. ASTM International, West Conshohocken, PA.

Aubert, B. 1987. Triza erytreae del Guercio and Diaphorina citri Kuwayama (Homoptera: Psylloidea), the two vectors of citrus greening disease: Biological aspects and possible control strategies. Fruits 42:149-162.

Aubert, B. 1990. High density planting (HDP) of jiagon mandarine in the lowland area of Shantou (Guangdong China) and implications for greening control, p. 149-157. In: B. Aubert, S. Tontyaporn, and D. Buangsuwon (eds.). Proc. Asia Pacific Intl. Conf. Citriculture, Chiang Mai, Thailand, 4-10 Feb. 1990. Intl. Soc. Citriculture, Riverside, CA

Gonzales, C.I. and R.C. Viñas. 1981. Field performance of citrus varieties and cultivars grown under control measures adopted against leaf mottling (greening) disease in the Phillipines. Proc. Intl. Soc. Citriculture 1:463-464.

Halbert, S.E. and K.L. Manjunath. 2004. Asian citrus psyllids (Sternorrhyncha: Psyllidae) and greening disease of citrus: A literature review and assessment of risk in Florida. Fla. Entomol. 87:330-353.

Hoffmann, W.C., T.W. Walker, V.L. Smith, D.E. Martin, and B.K. Fritz. 2007a. Droplet-size characterization of handheld atomization equipment typically used in vector control. J. Amer. Mosquito Control Assn. 23:315-320.

Hoffmann, W.C., T.W. Walker, D.E. Martin, J.A.B. Barber, T. Gwinn, V.L. Smith, D. Szumlas, Y. Lan, and B.K. Fritz. $2007 \mathrm{~b}$. Characterization of truckmounted atomization equipment used in vector control. J. Amer. Mosquito Control Assn. 23:321-329.

Roistacher, C.N. 1996. The economics of living with citrus diseases: Huanglongbing (greening) in Thailand, p. 279-285. In: J.V. Graça, P. Moreno, and R.K. Yokomi (eds.). Proc. 13th Conf. Intl. Org. Citrus Virologists. IOCV, Riverside, CA. 


\section{Technology and Product Reports}

Stover, E., D. Scotto, and J. Salvatore. 2002. Pesticide spraying in Indian River grapefruit: I. Survey of current practices. HortTechnology 12:454-460.

Stover, E., D. Scotto, C. Wilson, and M. Salyani. 2003. Pesticide spraying in Indian River grapefruit: II. Overview of factors influencing spray efficacy and off-target deposition. HortTechnology 13:166177.

Supriyanto, A. and A.M. Whittle. 1991. Citrus rehabilitation in Indonesia, p. 409413. In: R.H. Brlansky, R.F. Lee, and L.W. Timmer (eds.). Proc. 1lth Conf. Intl. Org. Citrus Virologists. IOCV, Riverside, CA.
Tolley, I.S. 1990. The relation of nursery production with orchard planning and management, p. 77-82. In: B. Aubert, S. Tontyaporn, and D. Buangsuwon (eds.). Proc. Asia Pacific Intl. Conf. Citriculture, Chiang Mai, Thailand, 4-10 Feb. 1990. Intl. Soc. Citriculture, Riverside, CA.

\section{Appendix}

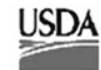

United States Department OI Agriculure Agricultural Research Service

\section{USDA - ARS - Aerial Application Technology Group College Station, TX Nozzles, Aug 2009}

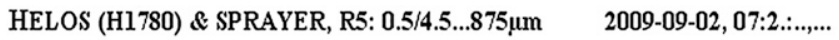

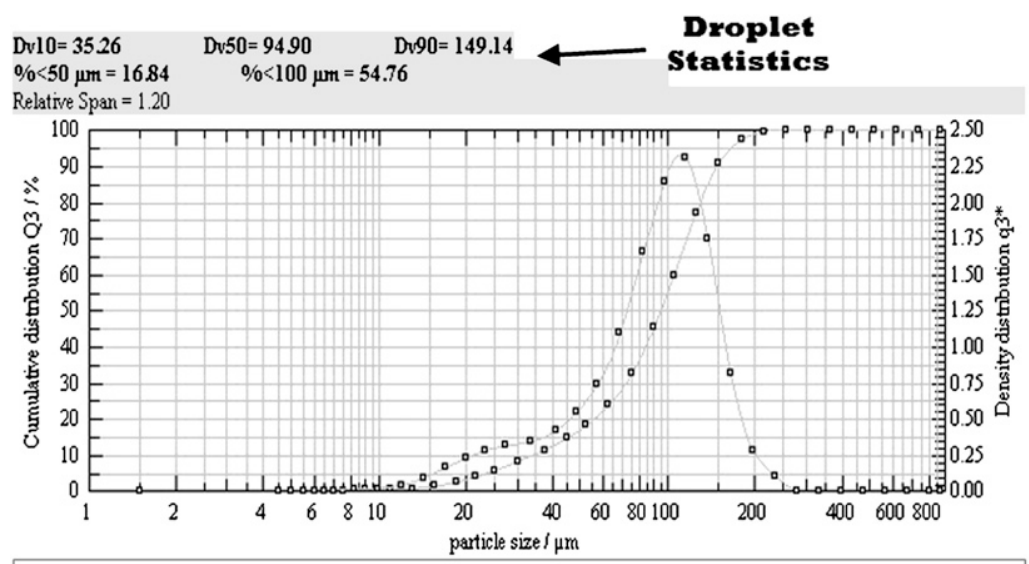

\section{Droplet Statistics}

Dv50 $=$ VMD $=$ Volume Median Diameter $=$ Diameter representing $50 \%$ of the Spray volume. This is the value specified on some labels.

DV10 = Diameter representing $10 \%$ of the Sprayvolume;

Dv90 = Diameter representing $90 \%$ of the Sprayvolume . All units are in microns $(\mu \mathrm{m})$.

Fig. 2. Handout given to applicators at the citrus sprayer calibration rodeos to explain the results of the tests; $1 \mu \mathrm{m}=1$ micron, 1 gal $=3.7854 \mathrm{~L}, 1 \mathrm{psi}=6.8948 \mathrm{kPa}, 1 \mathrm{~m} / \mathrm{s}=1 \mathrm{~m} \cdot \mathrm{S}^{-1}=2.2369 \mathrm{mph}$. 